\title{
Human Uptake of Eggshell Powder as an Alternate Source of Calcium
}

\author{
Md. Kobirul Islam ${ }^{1,2}$, Tahrima Arman Tusty ${ }^{1}$, Anwarul Azim Akhand ${ }^{1}$ \\ and Nazmul Ahsan ${ }^{1}$ \\ ${ }^{1}$ Department of Genetic Engineering and Biotechnology, University of Dhaka, Dhaka-1000, Bangladesh \\ ${ }^{2}$ Department of Biotechnology and Genetic Engineering, Noakhali Science and Technology University \\ Noakhali-3814, Bangladesh
}

(Received: April 7, 2019; Accepted: September 1, 2019; Published (web): December 19, 2019)

\begin{abstract}
Calcium (Ca) plays important structural and physiological roles in our body. Usually, our body meets up its $\mathrm{Ca}$ need from dietary sources. In developing countries like Bangladesh, most of the people cannot afford Carich foods. So, Ca supplements are generally prescribed to deficient individual that usually costs high. It is, therefore, necessary to find out an alternative and cheap source of Ca supplement especially in Bangladesh. Considering the above facts, the main focus of this study was to explore the possibility of using the egg shell as a source of Ca. In his study, discarded eggshells were collected, washed, decontaminated properly and ground to a fine powder. Washing with tap water followed by 10 min boiling completely decontaminated the eggshells. On an average 3.45, 5.91, 4.5 and $4.55 \mathrm{~g}$ of eggshell powder (ESP) per shell were obtained from a domesticated fowl, domestic duck, white leghorn, and rhode island red, respectively. Particle size was measured using scanning electron microscope and the size ranged between 3.47-5.94 $\mu \mathrm{m}$. The Ca contents were found as 38.65, 35.0, 24.85 and $35.73 \mathrm{~g}$ in domesticated fowl, domestic duck, white leghorn, and rhode island red, respectively per $100 \mathrm{~g}$ of ESP. Taking daily Ca requirements into account, we observed that powder from almost half of an eggshell is sufficient to fulfill the daily Ca need. The amount of magnesium $(\mathrm{Mg})$ in $100 \mathrm{~g}$ ESPs was found to be 45.37, 32.48, 45.17 and $45.27 \mathrm{mg}$ and that of iron (Fe) was 35.07, 33.47, 31.91 and $33.06 \mathrm{mg}$ in domesticated fowl, domestic duck, white leghorn, and rhode island red, respectively. Various toxic heavy metals such as chromium $(\mathrm{Cr})$, lead $(\mathrm{Pb})$ and arsenic $(\mathrm{As})$ contents remained below the detection level in ESP samples. Organoleptic tests revealed that the ESP does not have any objectionable effects on the texture and flavor of ESP-fortified foods and juice. These results suggested that the ESP can be used as an alternative and important cheap source of $\mathrm{Ca}$ and other beneficial micronutrients for human being. However, it is necessary to create the awareness and public perception regarding the use of EPS.
\end{abstract}

Key words: Calcium, egg shell powder, organoleptic test, heavy metals.

\section{INTRODUCTION}

Calcium $(\mathrm{Ca})$ is the most abundant mineral found in the human body to maintain strong bones and to carry out various important physiological functions. Almost all $\mathrm{Ca}$ is deposited in bones and teeth, where it supports to keep their structure with appropriate hardness. ${ }^{1}$ The rest of the $\mathrm{Ca}$ is present in nerve cells, body tissues, blood and other body fluid. ${ }^{1}$ $\mathrm{Ca}$ is a key component in muscle movement where it

Correspondence to: Nazmul Ahsan

Tel. 880-2-9661920/7822;

E-mail.nahsan@du.ac.bd

Dhaka Univ. J. Pharm. Sci. 18(2): 249-255, 2019 (December)

DOI: https://doi.org/10.3329/dujps.v18i2.44465 works as a switch to turn muscular movement on and off. Increase in $\mathrm{Ca}$ concentration triggers energyconsuming chain reaction that causes myofilaments to change shape and shorten. Shortening of thousands of myofilaments ultimately lead to muscle contraction. ${ }^{2}$ On the other hand, when the $\mathrm{Ca}$ concentration in the vicinity of the myofilaments drops, the muscle returns to the relaxed state. ${ }^{3} \mathrm{Ca}$ is associated with cell signaling by playing active roles in relaying messages from the brain to every part of the body. ${ }^{4}$ It plays a role in releasing hormones and enzymes that helps blood vessels to move blood throughout the entire body. ${ }^{5}$ 
$\mathrm{Ca}$ level in serum is tightly regulated where the body uses bones as a $\mathrm{Ca}$ reservoir in critical situations to maintain a constant concentration of $\mathrm{Ca}$ in blood, muscle and intercellular fluid. Excess $\mathrm{Ca}$ is stored in bones where a balance is maintained between resorption and deposition. ${ }^{6}$ This balance is largely dependent on the age of individual person. In adults, the tendency of bone decay is higher particularly among postmenopausal women, whereas bone formation is higher during the periods of growth of children and adolescents. In early and middle adulthood, both processes are relatively equal. ${ }^{7}$ As a result, people are at increased risk of Ca deficiency with aging.

The eggshell powder has already been greatly valued in some developed countries as a very good source of $\mathrm{Ca}^{8,9}$ There was no difference in $\mathrm{Ca}$ absorption from purified $\mathrm{CaCO}_{3}$ and eggshell powder as demonstrated in a previous study. ${ }^{10}$ An increase in bone $\mathrm{Ca}$ concentration was observed in postmenopausal women suffering from osteoporosis, who received eggshell powder with vitamin $\mathrm{D}_{3}$ and magnesium supplementation. ${ }^{11}$

In Bangladesh, no report has so far been published considering the use of eggshell as a source of $\mathrm{Ca}$ for human. A huge number of eggs are consumed each day and the eggshells are mostly discarded. However, waste eggshells can be a good and cheap source of $\mathrm{Ca}$ and other minerals. Consumption of eggshell fortified foods/drinks could fulfill the $\mathrm{Ca}$ requirement in peoples of developing countries like Bangladesh. It would reduce the cost and make Ca supplements available to every person. In this study, we showed that locally available different types of eggshell are rich in $\mathrm{Ca}$ and it is possible to use the eggshell powder as an important alternative source of $\mathrm{Ca}$ as well as other minerals.

\section{MATERIALS AND METHODS}

Collection and decontamination of eggshells. Four different types of eggshell available in Bangladesh were collected from local restaurants (domestic duck, white leghorn, and rhode island red) and village areas (domesticated fowl). Immediately after collection, the eggshells were cleaned using tap water and air-dried before being processed in the laboratory. The eggshells were then boiled at different time duration $(5,10$ and $20 \mathrm{~min})$ to determine the optimum boiling time required for decontamination.

Preparation of eggshell powder (ESP). Decontaminated eggshells were oven dried at $80^{\circ} \mathrm{C}$ for $2 \mathrm{hrs}$. These were then processed into powder using the commercially available blending machine (Phillips, HR2118/01). To obtain the fine eggshell powder (ESP), it was then sieved through 2 layered fine net (sieved size $50 \mu \mathrm{m}$ ). The amount of ESP per eggshell was then calculated by simply dividing the total amount obtained with the number of eggshells used.

Determination of particle size of ESP. ESP obtained from four samples was examined under a scanning electron microscope (JEOL- JSM-6490LA). Images were obtained at different magnifications and the size of eggshell particles was analyzed using the software provided by the company (JEOL).

Digestion of EPS and determination of $\mathrm{Ca}$ and others mineral content. The EPS samples were dried in an oven at $90^{\circ} \mathrm{C}$ for $1 \mathrm{hr}$. The samples $(0.5 \mathrm{~g})$ were then placed in a Teflon digestion vessel containing $7 \mathrm{ml}$ of ultra-pure $\mathrm{HNO}_{3}$ and $1 \mathrm{ml}$ of $\mathrm{H}_{2} \mathrm{O}_{2}$ (according to the digestion program (power-1600w; ramp time-15 $\mathrm{min}$; temperature- $2000^{\circ} \mathrm{C}$; holding time-15 min; cooling time-10 min). ${ }^{12}$ After digestion, the sample solution was cooled down at room temperature and transferred into acid cleaned $100 \mathrm{ml}$ volumetric flask. Then the volume was made up to $100 \mathrm{ml}$ with double distilled water. The concentration of $\mathrm{Ca}, \mathrm{Mg}, \mathrm{Fe}, \mathrm{Pb}, \mathrm{Cr}$, and $\mathrm{As}$ was determined by graphite furnace atomic absorption spectrometer (Shimadzu, AA-7000). The concentration of each mineral was based on the average values of three replicate samples. Data are expressed as mean \pm SD.

Addition of eggshell to food. The EPS was used to prepare sandwiches, juice, and noodles. Texture and flavor of the different food items were evaluated by 20 volunteers (10 male and 10 female; age between 20 to 45 years), who were not involved in 
this work. All have good health and gave written informed consent to evaluate the foods. The score was considered as $* * * *$ no changes; $* * *$ minimal changes; ** moderate changes; and * important changes that make the food unacceptable.

\section{RESULTS}

Decontamination of eggshells by washing and boiling. It was found that washing with water greatly reduced microbes from the surface of eggshells. To decontaminate completely, washed eggshells were boiled for different time durations (5, 10, 20 and 30 $\mathrm{min})$. We observed that boiling for $10 \mathrm{~min}$ completely decontaminated the eggshell surfaces.

Amount of eggshell powder (ESP) obtained from each shell. The average amount $(\mathrm{g})$ of ESP obtained from each shell was determined. The average weight of each shell of domesticated duck

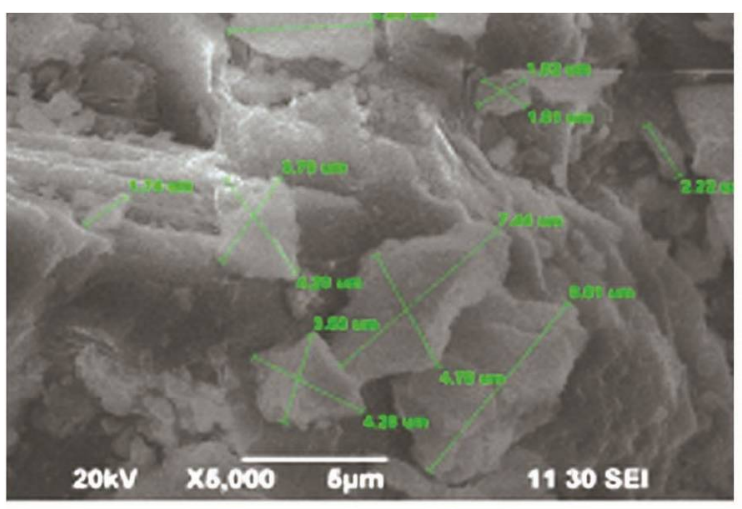

A. Domesticated fowl

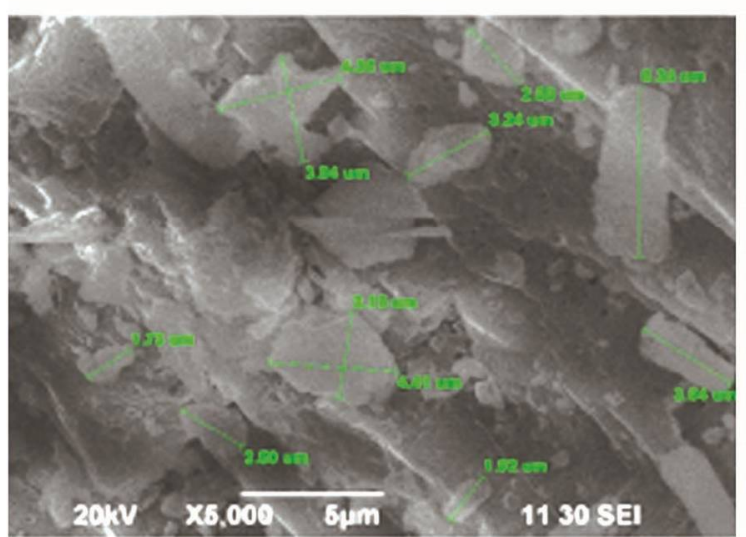

C. White leghom was $6.72 \mathrm{~g}$ and the obtained ESP was $5.91 \mathrm{~g}$. The average weight of other eggshells such as domesticated fowl, white leghorn and rhode island red ware 4.17, 5.18 and $5.36 \mathrm{~g}$ and the obtained ESP were $3.45,4.50$ and $4.55 \mathrm{~g}$, respectively.

Determination of particle size after grinding and sieving of eggshells. Our target was to use ESP consumption as a source of Ca. Egg shells were, therefore, ground and sieved through two layered fine net to get very fine particles. The particles, obtained from four different types of eggshell after grinding and sieving, were observed under a scanning electron microscope. The average particle size of domesticated fowl, domestic duck, white leghorn and rhode island red was found $4.06 \pm 2.07,4.77 \pm 1.16$, $3.47 \pm 1.25$ and $5.94 \pm 1.80 \mu \mathrm{m}$, respectively (Figure 1 and Table 1).

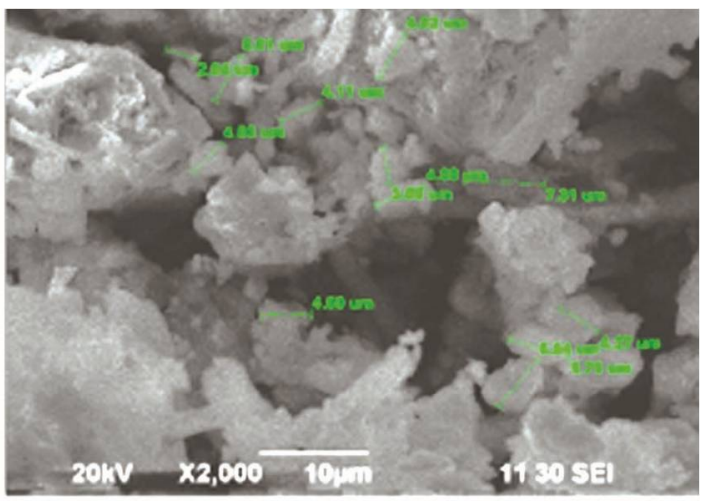

B. Domestic duck

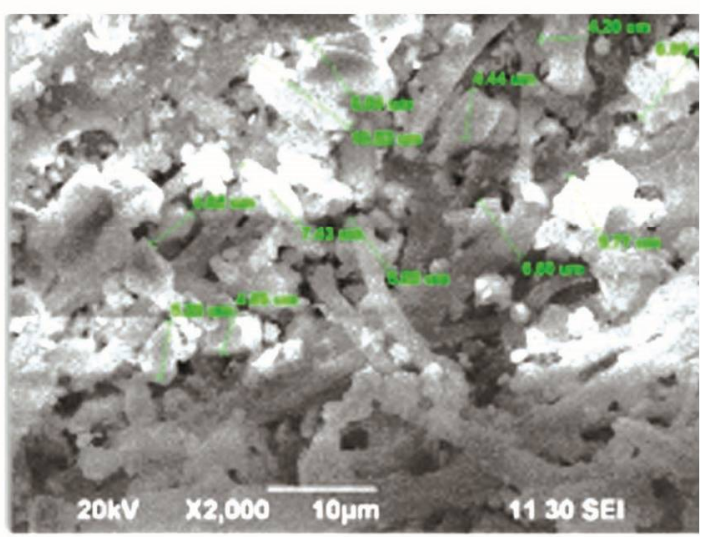

D. Rhode island red

Figure 1. Photograph of eggshell powder particles taken by scanning electron microscope (Model-JSM-6490LA). 
Table 1. Mean particle size of various eggshell powder (ESP).

\begin{tabular}{lc}
\hline Type & $\begin{array}{c}\text { Average particle size } \\
\text { (mean } \pm \text { SD) } \mu \mathrm{m}\end{array}$ \\
\hline Domesticated fowl & $4.06 \pm 2.07$ \\
Domestic duck & $4.77 \pm 1.16$ \\
White leghorn & $3.47 \pm 1.25$ \\
Rhode island red & $5.94 \pm 1.80$ \\
\hline
\end{tabular}

Domesticated fowl eggshells contain a comparatively higher amount of $\mathrm{Ca}$. Eggshells are known to contain high $\mathrm{Ca}$ content. We next determined the amount of $\mathrm{Ca}$ in different types of eggshell used in this study. The amount of $\mathrm{Ca}$ in domesticated fowl, Rhode island red, domestic duck and white leghorn was $38.65,35.73,35.0$ and $24.85 \mathrm{~g}$ per $100 \mathrm{~g}$ of ESP, respectively (Table 2). These results demonstrated that the domesticated fowl contains the highest amount of $\mathrm{Ca}$, while the white leghorn contains the lowest amount among the four eggshells tested. The rhode island red egg is widely consumed in Bangladesh and therefore this eggshell may get more preference for use as a good source of Ca.

Table 2. Metal contents of eggshell powder (ESP).

\begin{tabular}{lcccccc}
\hline Eggshell types & $\begin{array}{c}\mathrm{Ca} \\
(\mathrm{mg} / 100 \mathrm{~g})\end{array}$ & $\begin{array}{c}\mathrm{Mg} \\
(\mathrm{mg} / 100 \mathrm{~g})\end{array}$ & $\begin{array}{c}\mathrm{Fe} \\
(\mathrm{mg} / 100 \mathrm{~g})\end{array}$ & $\begin{array}{c}\mathrm{Pb} \\
(\mathrm{mg} / 100 \mathrm{~g})\end{array}$ & $\begin{array}{c}\mathrm{Cr} \\
(\mathrm{mg} / 100 \mathrm{~g})\end{array}$ & $\begin{array}{c}\text { As } \\
(\mathrm{mg} / 100 \mathrm{~g})\end{array}$ \\
\hline Domesticated fowl & 38.65 & 45.37 & 35.07 & $\mathrm{BDL}$ & $\mathrm{BDL}$ & $\mathrm{BDL}$ \\
Domestic duck & 35 & 32.48 & 33.47 & $\mathrm{BDL}$ & $\mathrm{BDL}$ & $\mathrm{BDL}$ \\
White leghorn & 24.85 & 45.17 & 31.91 & $\mathrm{BDL}$ & $\mathrm{BDL}$ & $\mathrm{BDL}$ \\
Rhode island red & 35.73 & 45.27 & 33.06 & $\mathrm{BDL}$ & $\mathrm{BDL}$ & $\mathrm{BDL}$ \\
Lowest Detection & & & & $0.5 \mathrm{ppm}$ & $0.2 \mathrm{ppm}$ & $0.2 \mathrm{ppm}$ \\
Level & & & & & & \\
\hline
\end{tabular}

BDL: Below detection level, ppm: parts-per-million, Pb: Lead, Cr: Chromium, As: Arsenic

Table 3. Qualitative analyses of the organoleptic features of different ESP.

\begin{tabular}{|c|c|c|c|c|c|c|c|c|c|}
\hline \multirow{3}{*}{ Food } & \multirow{3}{*}{ Characteristic } & \multicolumn{2}{|c|}{ Domesticated fowl } & \multicolumn{2}{|c|}{ Domestic duck } & \multicolumn{2}{|c|}{ White leghorn } & \multicolumn{2}{|c|}{ Rhode island red } \\
\hline & & ESP & ESP & ESP & ESP & ESP & ESP & ESP & ESP \\
\hline & & -ve & $+\mathrm{ve}$ & -ve & $+\mathrm{ve}$ & -ve & $+\mathrm{ve}$ & $-\mathrm{ve}$ & $+\mathrm{ve}$ \\
\hline \multirow[t]{2}{*}{ Sandwich } & Texture & $* * * *$ & $* * * *$ & $* * * *$ & $* * * *$ & $* * * *$ & $* * * *$ & $* * * *$ & $* * *$ \\
\hline & Flavor & $* * * *$ & $* * * *$ & $* * * *$ & $* * * *$ & $* * * *$ & $* * * *$ & $* * * *$ & $* * * *$ \\
\hline \multirow[t]{2}{*}{ Noodles } & Texture & $* * * *$ & $* * * *$ & $* * * *$ & $* * * *$ & $* * * *$ & $* * * *$ & $* * * *$ & $* * *$ \\
\hline & Flavor & $* * * *$ & $* * * *$ & $* * * *$ & $* * * *$ & $* * * *$ & $* * * *$ & $* * * *$ & $* * * *$ \\
\hline \multirow[t]{2}{*}{ Juice } & Texture & $* * * *$ & $* * * *$ & $* * * *$ & $* * * *$ & $* * * *$ & $* * * *$ & $* * * *$ & $* * * *$ \\
\hline & Flavor & $* * * *$ & $* * * *$ & $* * * *$ & $* * * *$ & $* * * *$ & $* * * *$ & $* * * *$ & $* * * *$ \\
\hline
\end{tabular}

ESP + ve: Presence of eggshell powder; ESP - ve: Absence of eggshell powder; *Important changes that make the food unacceptable; $* *$ Moderate changes; $* * *$ Minimal changes; ****As usual. $\mathrm{N}=20$ (10 male and 10 female)

The presence of toxic metals was negligible in all four different types of ESP. Poultry feed, now-adays, is known to contain heavy metals that generate chances of the presence of heavy metals in ESP. If ESP is contaminated with heavy metals, it would rather be dangerous to use it as a source of $\mathrm{Ca}$. We, therefore, examined whether or not the heavy metals such as As, $\mathrm{Cr}$ and Pd were detectable in the ESPs.
The presence of these toxic heavy metals in ESPs was almost negligible when analyzed by graphite furnace atomic absorption spectrometer (Table 2).

ESP from domesticated fowl contain a higher amount of $\mathbf{F e}$ and $\mathrm{Mg}$. The ESP is not only a good source of $\mathrm{Ca}$, but also be a source of other inorganic elements. The presence of 45.37, 32.48, 45.17 and $45.27 \mathrm{mg}$ of $\mathrm{Mg}$ and 35.07, 33.47, 31.91 and $33.06 \mathrm{mg}$ 
of Fe per 100g ESP of domesticated fowl, domestic duck, white leghorn, and rhode island red were detected, respectively (Table 2).

Organoleptic test of foods fortified with ESP. It is evident from the above results that ESP can be used as a source of $\mathrm{Ca}$ and other nutritional elements. Some local foods were fortified with ESP and our interest was to know whether ESP had any effect on the flavor and/or texture of the fortified food. ESP was added in sandwich, noodles and juice, and the flavor and texture of the fortified food items were evaluated by a group of volunteers. The experiment was conducted on 10 male and 10 female volunteers who are familiar with these foods (Table 3). None of them shown any objection regarding the texture and flavor of the food items tested. Therefore, use of ESP-fortified foods could be an effective way of supplementing $\mathrm{Ca}$ and other nutritional elements.

\section{DISCUSSION}

We found that ESP is rich in Ca $(248-386 \mathrm{mg} / \mathrm{g})$, and the highest content was found in domesticated fowl $(386 \mathrm{mg} / \mathrm{g} \mathrm{ESP})$. Our result of higher $\mathrm{Ca}$ contents in eggshells is supported by earlier reports that also demonstrated higher contents of $\mathrm{Ca}$ in eggshells. ${ }^{13,14}$ The domesticated fowl usually are raised in an open area which creates opportunities for them to take various types of natural foods. This might have an impact in elevating the Ca-content of fowl eggshell. The lowest Ca-content was found in white leghorn's eggshell (248 mg/g ESP). As we know, the white leghorn chicken is raised in cages and the feed supplied to them might have lower amounts of $\mathrm{Ca}$ resulting in lower $\mathrm{Ca}$ contents in ESP. ESP from domestic duck and rhode island red contain a relatively higher amount of $\mathrm{Ca}$ and it was 350 and $357 \mathrm{mg}$ per $\mathrm{g}$ of ESP. Though domesticated fowl contains higher $\mathrm{Ca}$, it is less available than rhode island red. So it would be more feasible to use eggshell of rhode island red for commercial production of the Ca supplement in the future.

Eggshell is not only a natural source of $\mathrm{Ca}$ but also a source of other important minerals. We showed here that $\mathrm{Mg}$ content per $100 \mathrm{~g}$ of ESP ranges between 32.48 to $45.37 \mathrm{mg}$ and that of $\mathrm{Fe}$ content between 31.91 to $33.47 \mathrm{mg}$ in four different egg varieties. Both $\mathrm{Mg}$ and $\mathrm{Fe}$ are important essential minerals that play key roles as cofactors for various enzymatic reactions. In addition, $\mathrm{Fe}$, by being attached to hemoglobin, helps to transport oxygen throughout the body. ESP, as a good and cheap source of these minerals, can contribute greatly to carry out important physiological activities in individuals who are deficient of those minerals.

Eggshell may be contaminated with various pathogenic bacteria including Salmonella. ${ }^{15,16}$ A microbial risk factor can be avoided easily by washing and applying decontamination processes. Washing with tap water followed by boiling for 10 min as shown in this study was found to be enough to decontaminate the eggshell surface completely. Many studies also demonstrated potential contamination of eggs by various heavy metals through the consumption of contaminated feed by chickens. ${ }^{17-21}$ Although ESP is a good source of $\mathrm{Ca}$ and other essential minerals, co-existence of heavy metals in ESP would definitely be harmful rather than beneficial. Our results demonstrated that the amount of heavy metals such as lead, chromium and arsenic in the ESP of the four tested egg varieties is very negligible and very much below the toxic level. These results are encouraging because the ESP, prepared from local egg varieties, are safe for human consumption and can act as an effective $\mathrm{Ca} /$ mineral supplement.

If the ESP is directly used in foods or drinks as a source of $\mathrm{Ca}$, its particle size might be a factor in accepting/rejecting the ESP-fortified food items by the consumers. ${ }^{22}$ Observation of the particles under scanning electron microscopy revealed that the particle size was between 3.47- $5.94 \mu \mathrm{m}$. This size is small enough to be accepted by the consumers, and therefore ESP can directly be used in any food or drink as a source of $\mathrm{Ca}$ and other minerals.

The best way to use the ESP as a source of $\mathrm{Ca}$ is to add it to common foods. In our study, ESPfortified food or drink such as sandwich, noodles and fruit juice was prepared by adding ESP in an amount 
that contains an equivalent amount of $\mathrm{Ca}$ required daily for the young adults. ${ }^{23}$ The volunteers who consumed the fortified food items did not put objection regarding the changes of texture and taste of the foods and drink they tested. In the case of noodles, a minor fraction of the volunteers felt slight changes in texture. The outcome of this organoleptic tasting is quite encouraging for using ESP in various foods and juices to fulfill the daily need of $\mathrm{Ca}$.

In some developed countries, ESP has already been widely used as a source of $\mathrm{Ca}^{22,24}$ However, no study has so far been performed in Bangladesh to explore the use of ESP as a dietary source of $\mathrm{Ca}$. This study showed that the local egg shell is rich in $\mathrm{Ca}$ and it is possible to use ESP as a promising and alternative cheap source of $\mathrm{Ca}$ for human nutrition. This inexpensive source of $\mathrm{Ca}$ may play a greater role in the health sector, particularly by strengthening the bones of people suffering from osteoporosis.

\section{REFERENCES}

1. Pravina, P., Sayaji, D. and Avinash, M. 2013. Calcium and its role in human body. Int. J. Res. Phar. Biomed. Sci. 4, 659668.

2. Biesiadecki, B.J. 2016. Myofilament modulation of contraction. Arch. Biochem. Biophys. 601, 1-3. doi:10.1016/j.abb. 2016.05.003.

3. Williams, A.B., Decourten-Myers, G.M., Fischer, J.E., Luo, G., Sun, X. and Hasselgren, P.O. 1999. Sepsis stimulates release of myofilaments in skeletal muscle by a calciumdependent mechanism. The FASEB J. 13, 1435-1443.

4. Clapham, D.E. 1995. Calcium signaling. Cell 80, 259-268.

5. Copp, D.H. and Shim, S. 1963. The homeostatic function of bone as a mineral reservoir. Oral Surg. Oral Med. Oral Pathol. Oral Radiol. 16, 738-744.

6. Fleming, K.H. and Heimbach, J.T. 1994. Consumption of calcium in the US: food sources and intake levels. The $J$. Nutri.124, 1426S-1430S.

7. Pak, C.Y. and Walsdorf, N.B. 1989. Liquid calcium supplementation from readily soluble mixtures of calcium compound and citric acid. Google Patents.

8. Rovenský, J., Stancíková, M., Masaryk, P., Svík, K. and Istok, R. 2003. Eggshell calcium in the prevention and treatment of osteoporosis. Int. J. Clin. Pharmacol. Res. 23, 83-92.
9. Schaafsma, A., Pakan, I., Hofstede, G.J., Muskiet, F.A., Van Der Veer, E. and De Vries, P. 2000. Mineral, amino acid, and hormonal composition of chicken eggshell powder and the evaluation of its use in human nutrition. J. Poult. Sci. 79, 1833-1838.

10. Schaafsma, A. and Beelen, G.M. 1999. Eggshell powder, a comparable or better source of calcium than purified calcium carbonate: Piglet studies. J. Sci. Food Agri. 79, 1596-1600.

11. Czernichow, S., Fan, T., Nocea, G. and Sen, S.S. 2010. Calcium and vitamin D intake by postmenopausal women with osteoporosis in France. Curr. Med. Res. Opin. 26, 1667 74. doi: 10.1185/03007995.2010.483658.

12. Sreenivasa, R. J., Vasudeva, R. Y., Devindra, S. and Longvah, T. 2014. Analysis of heavy metal concentrations in Indian marine fish using ICP-MS after closed vessel microwave digestion method. Int. J. Anal. Bioanal. Chem. 4, 67-73.

13. Olgun, O., Yildiz, A.Ö. and Cufadar, Y. 2015. The effects of eggshell and oyster shell supplemental as calcium sources on performance, eggshell quality and mineral excretion in laying hens. Indian J. Anim. Res. 49, 205-209.

14. Gongruttananun, N. 2011. Effects of Using Ground Eggshells as a dietary calcium source on egg production traits, hatching performance and eggshell ultra structure in laying hens. Kasetsart J. Nat. Sci. 45, 209-220.

15. Fardows, J. and Shamsuzzaman, S.M. 2015. Detection of potential pathogenic aerobic bacteria from egg shell and egg contents of hen collected from poultry. Bang. Med. Res. Counc. Bull. 41, 67-72.

16. Braden, C.R. 2006. Salmonella enterica serotype enteritidis and eggs: a national epidemic in the United States. Clin. Infect. Dis. 43, 512-517.

17. Ayas, Z., Celikkan, H. and Aksu, M.L. 2008. Lead (Pb) and copper $(\mathrm{Cu})$ concentration in the eggshells of Audouin's gull (Larus audouinii) in Turkey. Turk. J. Zool. 32, 379-384.

18. Dauwe, T., Bervoets, L., Blust, R., Pinxten, R. and Eens, M. 1999. Are eggshells and egg contents of great and blue tits suitable as indicators of heavy metal pollution? Belg. J. Zool. 129, 439-447.

19. Mora, M.A. 2003. Heavy metals and metalloids in egg contents and eggshells of passerine birds from Arizona. Environ. Pol. 125, 393-400.

20. Dauwe, T., Janssens, E., Bervoets, L., Blust, R. and Eens, M. 2005. Heavy-metal concentrations in female laying great tits (Parus major) and their clutches. Arch. Environ. Conta. Toxicol. 49, 249-256. 
21. Islam, M.S., Kazi, A.M.I, Hossain M.M., Ahsan, M.A. and Hossain A.M. 2007. Propagation of heavy metals in poultry feed production in Bangladesh. Bangladesh J. Sci. Indus. Res. 42, 465-474.

22. Brun, L.R., Lupo, M., Delorenzi, D.A., Di Loreto, V.E. and Rigalli, A. 2013. Chicken eggshell as suitable calcium source at home. Int. J. Food Sci. Nutri. 64, 740-743.
23. Ross, A.C., Taylor, C.L., Yaktine, A.L. and Del Valle, H.B. 2010. Dietary reference intakes for vitamin D and Calcium, Food and Nutrition Board, Institute of Medicine. Dietary Reference Intakes for Calcium and Vitamin D. Washington, DC: National Academy Press.

24. Hassan, N.M.M. 2015. Chicken eggshell powder as dietary calcium source in biscuits. World J. Dairy Food Sci. 10, 199-206. 